\title{
Risk factors associated with early childhood caries - a case control study
}

Marina de Deus Moura de Lima ${ }^{a}$, Zacarias Soares Brito-Neto ${ }^{a}$, Heylane Oliveira Amaral ${ }^{a}$, Cacilda Castelo Branco Lima ${ }^{a}$, Marcoeli Silva de Moura ${ }^{a}$, Lúcia de Fátima Almeida de Deus Moura ${ }^{a}$

\begin{abstract}
Objective: The aim of this study was to determine the risk factors associated with early childhood caries (ECC).

Methods: It was an observational retrospective case-control study. The case group consisted of all patients diagnosed with ECC in the records of an active program of maternal and child care. The control group was composed of an equal number of children, matched for gender and age, who attended the program and did not have ECC. The process of data collection consisted of completing a pre-established schedule to analyse variables related to the mother/caregiver and child. Statistical analysis was performed using the chi-squared and odds ratio $(\mathrm{OR})$, with alpha $(\alpha)=0.05$.

Results: History of caries in the mother $(\mathrm{OR}=2.61 ; \mathrm{Cl} 95 \%=1.45-4.67)$ and father $(\mathrm{OR}=1.72$; $\mathrm{Cl} 95 \%=1.02-2.89)$ were key determinants in the child being diagnosed with ECC.

Conclusions: The risk factors associated with ECC were the following: no oral hygiene acceptance, nocturnal feeding duration of more than 16 months, a daily intake of sugar greater than 4 times a day, a Baume type II maxillary arch, fewer than 3 consultations with the program, and a history of decay in the parents.
\end{abstract}

Key words: Dental caries; Child; Risk factors

\section{Fatores de risco associados à cárie precoce da infância - estudo caso-controle}

\section{RESUMO}

Objetivo: O objetivo deste estudo foi determinar os fatores de risco associados à carie precoce da infância (CPI). Metodologia: Foi um estudo observacional retrospectivo caso-controle. O grupo caso consistiu de todos os pacientes diagnosticados com CPI nos registros ativos de um programa odontológico de atenção maternoinfantil. O grupo controle foi composto por um número igual de crianças, pareadas por sexo e idade, que participaram do programa e não tinham $\mathrm{CPI}$. O processo de coleta de dados consistiu no preenchimento de uma ficha pré-estabelecida para analisar as variáveis relacionadas à mãe/cuidador e a criança. A análise estatística foi realizada utilizando o teste do qui-quadrado e razão de chances (OR), com alfa $(\alpha)=0,05$.

Resultados: $\mathrm{A}$ CPI foi associada à história de cárie na mãe ( $\mathrm{OR}=2.61$; IC $95 \%=1.45-4.67)$ e no pai $(\mathrm{OR}=1.72$; IC 95\%=1.02-2.89)

Conclusões: Os fatores de risco associados à CPI foram: não aceitação higiene oral, duração da alimentação noturna de mais de 16 meses, ingestão diária de açúcar superior a 4 vezes ao dia, arco superior tipo II de Baume, menos de 3 consultas ao programa, e história de cárie nos pais.

Palavras-chave: Cárie dentária; Criança; Fatores de risco a Department of Pathology and Dental Clinic Postgraduate Programme in Dentistry, Federa University of Piauí, Teresina, Piauí, Brazil

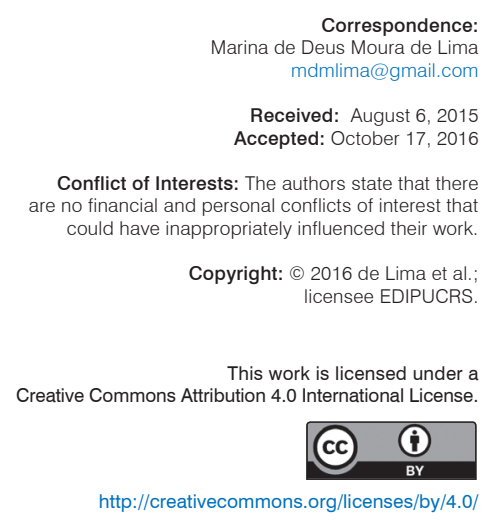




\section{INTRODUCTION}

Early Childhood Caries (ECC) can be defined as the "presence of one or more decayed tooth surfaces (noncavitated or cavitated), lost or restored in children younger than six years" [1]. ECC is considered a public health problem because it is highly prevalent, it is preventable, there is effective treatment available and its sequelae cause physical and emotional disorders in individuals [2,3]. Moreover, it has been shown that children with ECC have a worse quality of life related to oral health than those free of the disease [4,5].Several preventive strategies have been used in recent decades to reduce the prevalence and severity of dental caries in the world, including the use of fluoride in its various forms of applications and the implementation of public policies regarding educational and preventive changes [6]. Epidemiological studies on the primary dentition have not reported the same decline in the prevalence of dental caries in permanent teeth examined, and these studies note an increase in the average decayed-missing-filled teeth (dmft) index, with high proportions of untreated carious lesions occurring up to five years of age $[7,8]$.

The assessment of social and environmental factors that directly interfere with the development of ECC can significantly contribute to identifying patients at risk and aid consequent implementation of public services that work in an interdisciplinary way to treat a multifactorial disease of unknown aetiology. The age range of children with ECC should be prioritized by current public health policies $[8,9]$.

Although non-biological factors associated with ECC have been previously identified, those associated with the caregivers are not fully understood [10]. The determination of risk factors associated with ECC allow the development of strategies to work with problem solving, treatment, control and prevention of the disease refer to both children with the disease and those exposed to risk situations.

From this perspective, a group of professors at the Dentistry School, Federal University of Piauí (UFPI) started a university extension project on April 27, 1997 in Teresina, Piauí, Brazil - the Preventive Program for Pregnant Women and Babies (PPPWB) - whose goals are focused on the recovery and maintenance of the oral health of pregnant women and children aged zero to 36 months. The program's activities are developed at the Institute of Social Perinatology, Piauí (ISPP) by students of the undergraduate dental course at UFPI under the supervision and guidance of professors [11].

The objective of this study is to determine the risk factors associated with ECC and to determine the prevalence of ECC in the Dental Care Program Maternal and Child Health at Federal University of Piauí.

\section{METHODS}

This observational retrospective case-control study was ethically conducted in accordance with the Declaration of Helsinki. It was initiated after approval by the Ethics Committee in Research of the Federal University of Piauí (UFPI) (CAAE: 0240.0.045.000-10).

To determine the groups, all records of a maternal and child care program [11] were inspected to select all patients diagnosed with ECC according to the criteria of the American Academy of Pediatric Dentistry [1].

The control group was composed of an equal number of children, matched for gender and age, at random, who attended the same program and were not diagnosed with ECC.

The data collection was performed by the review of the records and then the data were transcribed to a form designed specifically for this study. We analysed the following variables related to the mother / caregiver: identity of the caregiver for most days, number of prenatal visits, the education of father and mother, family income, whether the mother visited a dentist during pregnancy, whether the mother received dental education during pregnancy, individual who performed the oral brushing on the child, history of caries in the mother or father. The following variables regarding the children were evaluated: gender, age, whether the child was born at full term, birth weight, whether the child lives with both parents in the same house, when the child began practicing oral hygiene, whether oral hygiene is accepted, duration of exclusive breast feeding through the night, whether the child used a bottle during sleep, daily intake of sugar, maxillary and mandibular arch type (12) and the number of dental program queries.

Sugar intake was assessed by analysing the daily food recall (24 hours), and scores were defined as follows: high (intake of sucrose on demand or more than 6 times), medium (intake of sucrose between 4 to 6 times) and low (intake of sucrose up to 3 times). Data regarding the $\mathrm{dmft}$ index values were transcribed to form the study as a continuous variable.

Statistical analysis was performed using the Statistical Package for Social Sciences (SPSS) ${ }^{\circledR}$ version 17.0 (SPSS Inc, Chicago, USA) using the chi-square $\left(\chi^{2}\right)$ homogeneity, with alpha $(\alpha)=0.05$ (significance level). To assess homogeneity between the study groups regarding variables related to the mother/caregiver and the child, a chi-squared test was used (confidence interval 95\%). To carry out the preliminary exploratory analysis, variables were transformed into binary form and tested for association with the presence of caries, using the chi-squared test and odds ratio (OR) with a confidence interval of $95 \%$, applied to each variable separately.

The study preserved only those variables whose effect was significant $(p<0.05)$ for the occurrence of caries. Multivariate logistic regression was performed for each variable individually, starting from the one with the largest odds in the univariate analysis. In the final model, we kept only those variables statistically associated with the event. 


\section{RESULTS}

Table 1 describes the sample distribution according to gender and age of patients with Early Childhood Caries. $50.38 \%$ were male and $49.62 \%$ female. The average age was 2.72 years $( \pm 0.693)$, and $39.24 \%$ in the age $1-2$ years old and $46.79 \%$ were aged 3-4 years old.

The teeth most frequently affected by ECC were: upper incisors, and first molars (Graphic 1).

Of the 3,374 records contained in the active dental program binder, $140(4 \%)$ presented in dental chart teeth with white spot lesions and $390(11 \%)$ were cavitated or lost due to caries or restored. Thus, the prevalence of program the ECC was $16.0 \%$.

The average value of the $\mathrm{dmft}$ in patients with ECC was equal to $3.25(\mathrm{SD} \pm 3.62)$ and the value of the modified $\mathrm{dmft}$ index, including active white spot lesions, was equal to $4.08(\mathrm{SD} \pm 3.28)$.

It was observed that 322 children (61\%) in the ECC group already had carious lesions at the first visit, and 208 $(39 \%)$ did not have the disease. A total of $125(60 \%)$ were diagnosed after 2-3 visits, 65 children (31\%) were diagnosed after 4-6 visits and 18 children (9\%) were diagnosed after seven or more visits.

Univariate analysis of variables related to the development of the early childhood caries is shown in Table 2.

In Table 3, it can be seen that a history of caries in the mother $(\mathrm{OR}=2.61$; IC $95 \%=1.45-4.67)$ and father $(\mathrm{OR}=1.72$; IC $95 \%=1.02-2.89)$ were key determinants in the child being diagnosed with ECC. Conversely, oral hygiene acceptance $(\mathrm{OR}=0.35$; IC $95 \%=0.22-0.56)$, no longer feeding nocturnally by the age of 16 months $(\mathrm{OR}=0.51$; IC $95 \%=0.39-0.65)$, intake of sugar less than or equal to 4 times a day $(\mathrm{OR}=0.37$; IC $95 \%=0.15-0.95)$, a Baume type I maxillary arch $(\mathrm{OR}=0.45$; IC $95 \%=0.26-0.78)$, and having a number of queries greater than or equal to $4(\mathrm{OR}=0.49$; IC $95 \%=0.29-0.82)$ were determinants of a lower chance that the child would be diagnosed with ECC.

Table 1. Sample distribution according to gender and age of patients with early childhood caries

\begin{tabular}{ccccc}
\hline \multirow{2}{*}{ Age (years) } & Gender & \multicolumn{2}{c}{ Male } & \multicolumn{2}{c}{ Female } \\
\cline { 2 - 5 }$<1$ & N & $\%$ & N & $\%$ \\
$1-2$ & 2 & 1.0 & 2 & 1.0 \\
$3-4$ & 93 & 35.0 & 115 & 43.0 \\
$\geq 5$ & 131 & 49.0 & 117 & 45.0 \\
Total & 41 & 15.0 & 29 & 11.0 \\
\hline
\end{tabular}

Graphic 1. Distribution of teeth affected by ECC

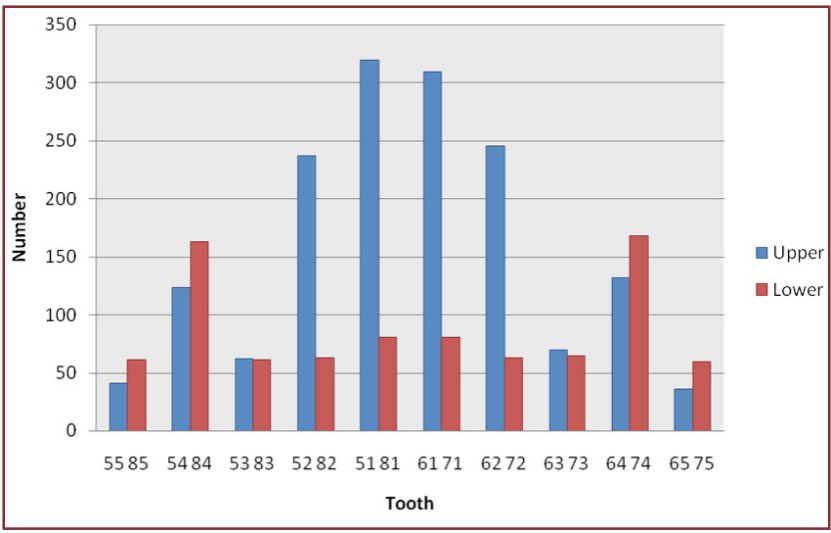

Table 2. Univariate analysis of variables related to the development of the early childhood caries.

\begin{tabular}{|c|c|c|c|c|c|}
\hline \multirow{2}{*}{ Variables } & \multicolumn{2}{|c|}{ Case } & \multicolumn{2}{|c|}{ Control } & \multirow{2}{*}{$\mathrm{P}$} \\
\hline & $\mathrm{N}$ & $\%$ & $\mathrm{~N}$ & $\%$ & \\
\hline Identity of the caregiver for most days & & & & & 0.246 \\
\hline Mother/father & 438 & 86.9 & 431 & 84.2 & \\
\hline Other person & 66 & 13.1 & 81 & 15.8 & \\
\hline Number of prenatal visits & & & & & 0.697 \\
\hline$\leq 3$ & 12 & 2.7 & 15 & 3.4 & \\
\hline$>3$ & 429 & 97.3 & 426 & 96.6 & \\
\hline Mother's education (years of formal study) & & & & & 0.002 \\
\hline$<11$ & 250 & 48.1 & 202 & 38.5 & \\
\hline$\geq 11$ & 270 & 51.9 & 323 & 61.5 & \\
\hline Father's education (years of formal study) & & & & & $<0.001$ \\
\hline$<11$ & 294 & 59.3 & 226 & 47.2 & \\
\hline$\geq 11$ & 202 & 40.7 & 253 & 52.8 & \\
\hline Family income (minimum wage) & & & & & $<0.001$ \\
\hline$<2$ & 97 & 18.5 & 47 & 9.0 & \\
\hline$\geq 2$ & 426 & 81.5 & 477 & 91.0 & \\
\hline
\end{tabular}


Table 2 (conclusion)

\begin{tabular}{|c|c|c|c|c|c|}
\hline \multirow{2}{*}{ Variables } & \multicolumn{2}{|c|}{ Case } & \multicolumn{2}{|c|}{ Control } & \multirow{2}{*}{$P$} \\
\hline & $\mathrm{N}$ & $\%$ & $\mathrm{~N}$ & $\%$ & \\
\hline Appointment at dentist during pregnancy & & & & & $<0.001$ \\
\hline Yes & 153 & 31.8 & 206 & 44.2 & \\
\hline No & 328 & 68.2 & 260 & 55.8 & \\
\hline Attended a dental lecture during pregnancy & & & & & 0.008 \\
\hline Yes & 169 & 32.8 & 208 & 40.8 & \\
\hline No & 347 & 67.2 & 302 & 59.2 & \\
\hline Individual who performed oral brushing on the child & & & & & 0.423 \\
\hline Parents & 485 & 94.4 & 472 & 95.9 & \\
\hline Child & 08 & 1.6 & 02 & 0.4 & \\
\hline Other person & 21 & 4.1 & 18 & 3.7 & \\
\hline Age when child began to brush teeth & & & & & $<0.001$ \\
\hline Before the 1st tooth erupted & 239 & 45.6 & 336 & 69.0 & \\
\hline After the 1st tooth erupted & 285 & 54.4 & 151 & 31.0 & \\
\hline History of caries in the mother & & & & & $<0.001$ \\
\hline Yes & 457 & 89.1 & 362 & 73.9 & \\
\hline No & 56 & 10.9 & 128 & 26.1 & \\
\hline History of caries in the father & & & & & $<0.001$ \\
\hline Yes & 419 & 81.5 & 300 & 66.2 & \\
\hline No & 95 & 18.5 & 153 & 33.8 & \\
\hline The child was born at full term & & & & & 0.175 \\
\hline Yes & 389 & 92.0 & 433 & 89.1 & \\
\hline No & 34 & 8.0 & 53 & 10.9 & \\
\hline Birth weight (pounds) & & & & & 0.500 \\
\hline$<2500$ & 48 & 11.3 & 48 & 9.9 & \\
\hline$\geq 2500$ & 377 & 88.7 & 436 & 90.1 & \\
\hline The child lives with both parents in the same house & & & & & 0.888 \\
\hline Yes & 409 & 83.5 & 419 & 83.8 & \\
\hline No & 81 & 16.5 & 81 & 16.2 & \\
\hline The child used a bottle during sleep (months) & & & & & 0.157 \\
\hline No use & 384 & 74.4 & 365 & 70.9 & \\
\hline$<6$ & 12 & 2.3 & 09 & 1.7 & \\
\hline$\geq 6$ & 120 & 23.3 & 141 & 27.4 & \\
\hline Number of dental program queries & & & & & 0.010 \\
\hline $1-3$ & 354 & 67.3 & 395 & 74.5 & \\
\hline$\geq 4$ & 172 & 32.7 & 135 & 25.5 & \\
\hline Oral hygiene acceptance & & & & & 0.028 \\
\hline Yes & 253 & 48.1 & 277 & 55.0 & \\
\hline No & 273 & 51.9 & 227 & 45.0 & \\
\hline Breastfeeding duration (months) & & & & & $<0.001$ \\
\hline$<6$ & 135 & 26.1 & 201 & 41.0 & \\
\hline$\geq 6$ & 382 & 73.9 & 289 & 59.0 & \\
\hline Duration of night-time breastfeeding (months) & & & & & $<0.001$ \\
\hline$\leq 16$ & 203 & 40.1 & 280 & 57.0 & \\
\hline$>16$ & 303 & 59.9 & 211 & 43.0 & \\
\hline Daily sugar ingestion & & & & & $<0.001$ \\
\hline$\leq 4$ times & 106 & 20.2 & 303 & 57.5 & \\
\hline$>4$ times & 420 & 79.8 & 224 & 42.5 & \\
\hline Maxillary arch type [Baume, 1950] & & & & & $<0.001$ \\
\hline Type I & 132 & 35.0 & 145 & 48.7 & \\
\hline ype II & 245 & 65.0 & 153 & 51.3 & \\
\hline
\end{tabular}

Variables unanswered were considered missing. 
Table 3. Logistic regression model of variables related to the development of the ECC. (Adjusted odds ratio)

\begin{tabular}{|c|c|c|c|}
\hline Variables & $\mathrm{OR}^{*}$ & $\left(\mathrm{Cl}{ }^{* *}-95 \%\right)$ & $\mathrm{p}$-value \\
\hline \multicolumn{4}{|l|}{ Oral hygiene acceptance } \\
\hline Yes & 0.35 & $0.22-0.56$ & $<0,001$ \\
\hline No & 1 & & \\
\hline \multicolumn{4}{|c|}{ Duration of night-time breastfeeding } \\
\hline$\leq 16$ months & 0.51 & $0.39-0.65$ & $<0.001$ \\
\hline$>16$ months & 1 & & \\
\hline \multicolumn{4}{|l|}{ Daily sugar ingestion } \\
\hline$\leq 4$ & 0.37 & $0.15-0.95$ & 0.04 \\
\hline$>4$ & 1 & & \\
\hline \multicolumn{4}{|c|}{ Upper maxillary arch (Baume, 1950) } \\
\hline Type I & 0.45 & $0.26-0.78$ & 0.005 \\
\hline Type II & 1 & & \\
\hline \multicolumn{4}{|c|}{ Number of appointments in the program } \\
\hline $1-3$ & 1 & & \\
\hline$\geq 4$ & 0.49 & $0.29-0.82$ & 0.006 \\
\hline \multicolumn{4}{|c|}{ History of caries in the mother } \\
\hline Yes & 2.61 & $1.45-4.67$ & 0.001 \\
\hline No & 1 & & \\
\hline \multicolumn{4}{|c|}{ History of caries in the father } \\
\hline Yes & 1.72 & $1.02-2.89$ & 0.04 \\
\hline No & 1 & & \\
\hline
\end{tabular}

\section{DISCUSSION}

Early childhood caries is a preventable disease. Therefore, the determination of the risk factors related to ECC is very important because individuals with greater susceptibility to its development can be identified, and greater attention can be directed to them $[9,13]$.

The present study has limitations inherent in a retrospective study; the main difficulty was related to the incompleteness of the records, but the statistical analysis excluded all variables that were not providing results from the calculations, minimizing the bias analysis.

The prevalence of ECC observed in the study population was $16 \%$, which may be explained by the fact that most patients seek care in dental program after parents have observed the presence of cavitations, as well as the fact that most children in our study were still breastfeeding on demand (Table 2). The prevalence of ECC in the general population is not well defined because the cases used may not represent the general population in this age group. The cases used included children who seek dental treatment, and there were methodological and conceptual differences that may hinder the comparison of results [14].

A greater prevalence of ECC was detected in children aged 3-4 years (Table 1). The age group with lower prevalence of ECC was $<1$ year, confirming the results of Tiberia et al. [15]. For ages $\geq 5$ years, we observed a lower prevalence $(15 \%$ and $11 \%$ for males and females, respectively) because the dental program aims to serve individuals up to 4 years of age, and older patients are referred for care to the Children's Dental Clinic of UFPI.

We note, however, that the process of motivation and oral health education is slow and gradual, so returning to dental program more than three times represented a protective factor in the development of dental caries (Table 3).

In this study, there is a greater possibility of children having a dmft index equal to zero when parents have a high educational level, so the oral health of children is a reflection of the attitudes and behaviour patterns of the parents [16]. In fact, the education level of parents has been previously considered an important socioeconomic indicator related to the prevalence of ECC $[9,17]$.

The development of carious lesions is directly related to the chronology of tooth eruption. The pattern of involvement of ECC is characteristic and pathognomonic for the condition (Graphic 1). The four lower incisors usually remain intact due to their location, which allows for self-cleaning and protection of the tongue, and also due to their proximity to the ducts of the sublingual glands, which allows for salivary protection. The four upper incisors are the teeth most affected because they are the first erupting in the maxilla and are strategically more exposed to the process involved in the initiation and progression of caries. Because bottle or breast milk ingested during sleep remains stored between the upper lip and upper incisors, there is an enabling environment for the cariogenic process to occur [18].

The results of this study showed that breastfeeding for a period greater than 16 months represents an important risk factor for the development of ECC (Table 3). Thus, after the eruption of the first teeth, mothers should be advised to suspend night-time feedings [1]. Feldens et al. [19] found that breastfeeding does not represent a risk factor if it occurs only once or twice a day. White et al. [20] stated that the lack of clarity and standardization of breastfeeding in the form of studies makes it difficult to compare results.

For dental caries to develop, the infant's mouth must be colonised by bacteria, and thinking that parents are usually responsible for the transmission of bacteria to the mouth of the child is dangerous [20]. It was observed that for parents who had poor oral health, the situation was repeated in their children. This fact can be attributed to a fatalistic culture so entrenched in certain social classes that having decayed teeth is a normal condition (Table 3 ). The results corroborate the views of several authors $[19,20]$. When parents have high counts of S. mutans in their saliva and/or carious lesions, the risk of transmission of cariogenic bacteria to their children is increased [21].

We observed an association between the intake of sugar more than 4 times a day and the development of ECC (Tables 2 and 3), a result that is consistent with data presented by Feldens et al. [19]. Diet is a factor difficult to control given that the intake of fermentable carbohydrates is directly related to economic and cultural conditions, leaving dentists to emphasise the importance of controlling dental plaque 
by brushing with fluoridated toothpaste. In addition to the biological and social factors, genetic factors should not be overlooked [22].

In this study, the frequency that the children attended the preventive program was considered a protective factor against ECC and was able to reduce the chances of children developing the disease by $51 \%$ (Table 3 ). Those responsible should be motivated to develop healthy hygiene habits, and to control the risk of developing tooth decay, it is necessary to have a constant reinforcement of health education [11].

Children with a Baume type II upper arch were more vulnerable to developing ECC (Table 3), a result corroborated by Soviero et al. [23]. The absence of interdental spacing makes it difficult to brush, and consequently, dental plaque is retained [24]. The arch type associated with the location of the caries lesion, there is an increase interproximal lesions in patients with type II arch Baume [25]. So, for children presenting a Baume type II upper arch, the use of a dental floss should be indicated as soon as possible.

\section{CONCLUSIONS}

From the results obtained, it can be concluded that the risk factors associated with ECC were: oral hygiene acceptance, breastfeeding duration greater than 16 months, a daily intake of sugar greater than four times a day, a maxillary Baume type II arch, a number of queries below PPGB four visits, and a history of caries in the mother and father. The prevalence of ECC in our study was $16 \%$, including white spot lesions.

\section{ACKNOWLEDGEMENTS}

We would like to acknowledge the financial support from CNPq

\section{REFERENCES}

1. American Academy on Pediatric Dentistry; American Academy of Pediatrics. Policy on early childhood caries (ECC): classifications, consequences, and preventive strategies. Pediatr Dent. 2008-2009; 30(7):40-3.

2. Khan MN, Cleaton-Jones PE. Dental caries in African preschool children social factors as disease markers. J Public Health Dent 1998;58(1):7-11. https://doi.org/10.1111/j.1752-7325.1998.tb02984.x

3. Davies GN. Early childhood caries-a synopsis. Community Dent Oral Epidemiol 1998;26(1):106-16. https://doi.org/10.1111/j.1600-0528.1998. tb02102.x

4. Arora A, Scott JA, Bhole S, Do L, Schwarz E, Blinkhorn AS. Early childhood feeding practices and dental caries in preschool children: a multicentre birth cohort study. BMC Public Health, 2011;11, 28. https://doi. org/10.1186/1471-2458-11-28

5. Acharya S, Tandon S. The effect of early childhood caries on the quality of life of children and their parents. Contemp Clin Dent 2011; 2(2):98-101. https://doi.org/10.4103/0976-237X.83069

6. Curzon MEJ, Preston AJ. Risk Groups: Nursing bottle caries in the elderly Caries Res 2004;38(1):24-33. https://doi.org/10.1159/000074359

7. Warren JJ, Steven ML, Kanellis MJ. Dental caries in the primary dentition: assessing prevalence of cavitated and non-cavitated lesions. J Public Health Dent 2002;62:109-14. https://doi.org/10.1111/j.1752-7325.2002. tb03430.x
8. Hashim R, Thomson WM, Ayres KM, Lewsey JD, Awad, M. Dental caries experience and use of dental UAE. Int J Paediatr Dent 2006; 16(4):257-62. https://doi.org/10.1111/j.1365-263X.2006.00746.x

9. Stephen A, Krishnan R, Ramesh M, Kumar VS. Prevalence of early childhood caries and its risk factors in 18-72 month old children in Salem, Tamil Nadu. J Int Soc Prev Community Dent. 2015;5(2):95-102. https:// doi.org/10.4103/2231-0762.155731

10. Seow WK. Environmental, maternal and child factors which contribute to early childhood caries: a unifying conceptual model. Int J Paediatr Dent 2012;22(3):157-68. https://doi.org/10.1111/j.1365-263X.2011. 01186.x

11. Moura LFAD, Moura MS, Toledo OA. Dental caries in children that participated in a dental program providing mother and child care. J Applied Oral Sci 2006;14:53-60. https://doi.org/10.1590/S167877572006000100011

12. Baume LJ. Physiological tooth migration and its significance for the development of occlusion. I the biogenetic course of the deciduos dentitions. J Dent Res 1950;29(2):123-32. https://doi.org/10.1177/0022 0345500290020301

13. Nishimura M, Oda T, Kariya N, Matsumura S, Shimono T. Using a caries activity test to predict caries risk in early childhood. J Am Dent Assoc 2008;139(1):63-71.https://doi.org/10.14219/jada.archive.2008. 0022

14. Tiano AV Moimaz SA, Saliba O Saliba NA Dental caries prevalence in children up to 36 months of age attending daycare centers in municipalities with different water fluoride content. J Appl Oral Sci 2009:17(1):39-44 https://doi.org/10.1590/S1678-77572009000100008

15. Tiberia MJ, Milnes AR, Feigal RJ, Morley KR, Richardson DS, Croft WG, et al. Risk factors for early childhood caries in Canadian preschool children seeking care. Pediatr Dent 2007;29(3):201-8.

16. Mattila ML, Rautava P, Sillanpa M, Paunio P. Caries in five-year-old children and associations with family-related factors. J Dent Res 2000;79:875-81. https://doi.org/10.1177/00220345000790031501

17. Prakash P, Subramaniam P, Durgesh BH, Konde S. Prevalence of early childhood caries and associated risk factors in preschool children of urban Bangalore, India: A cross-sectional study. Eur J Dent. 2012;6(2): 141-52.

18. Warren JJ, Weber-Gasparoni K, Marshall TA, Drake DR, Dehkordi-Vakil F, Dawson DV, et al. A longitudinal study of dental caries risk among very Iow SES children. Community Dent Oral Epidemiol 2008; 37(2):116-22. https://doi.org/10.1111/j.1600-0528.2008.00447

19. Feldens CA, Giuglibiani ERJ, Vigo A, Vítolo MR. Early feeding practices and severe early childhood caries in four-year-old children from Southern Brazil: A birth cohort study. Caries Research 2010; 44:445-52. https://doi. org/10.1159/000319898

20. White V. Breastfeeding and the risk of early childhood caries. Evid Based Dent 2008; 9(3):86-88. https://doi.org/10.1038/sj.ebd.6400603

21. Wakaguri S, Aida J, Osaka K, Morita M, Ando Y. Association between Caregiver Behaviours to Prevent Vertical Transmission and Dental Caries in Their 3-Year-Old Children. Caries Res 2011;45(3):281-6. https://doi. org/10.1159/000327211

22. Camacho MEI, Pérez LS, Pérez AG, Zepeda MAZ. Relationship between Severe Early Childhood Caries, Mother's Oral Health and Mutans Streptococci in a Low-Income Group: Changes from 1996 to 2007. J Clin Pediatr Dent 2009;33(3):241-6. https://doi.org/10.17796/ jcpd.33.3.p031w1w719vp2740

23. Soviero VM, Bastos EPS, Souza IPR. Dentição decídua: estudo da prevalência dos espaços interproximais em crianças brasileiras. Rev Odontol Univ São Paulo 1999;13(2):159-65. https://doi.org/10.1590/ S0103-06631999000200010

24. Osório LB, Vizzottoo MB, Marin EA, Lopes LFD. The relationship between Baume's arch and approximal fillings existence in deciduous dentition. Orthodontic Science and Practice 2008;1(1):54-9.

25. Limeira AB, Grinfeld S, Colares V, Valença PAM. Relationship between the arcade Baume, primate space and the caries. Full Dent. Sci 2011;2(5) 98-102. 